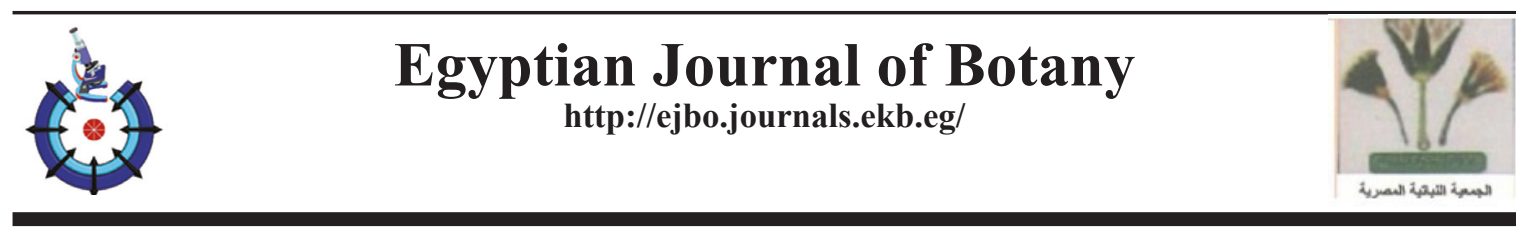

\title{
Evaluation of Different Biological Activities of Spirulina platensis Extracts
}

Soad M. Mohy EL. Din

Botany and Microbiology Department, Faculty of Science, Alexandria University, Alexandria, Egypt.

\begin{abstract}
PIRULINA is aquatic and photosynthetic blue green algae and it is a good source of c-phycocyanin pigments. It is widely utilized as food supplement because it contains significant amount of proteins. This investigation is an effort to study some of medicinal applications of $S$. platensis such as antioxidant capacity, antimicrobial, cholesterol- reduction and anticancer. Antimicrobial activity of methanol, acetone, chloroform and petroleum ether extracts of dried S. platensis was assayed against two fungi (Aspergillus flavus and Aspergillus niger) and four bacterial species (Staphylococcus aureus, Bacillus subtilis, Escherichia coli and Salmonella typhimurium). The $S$. platensis extracts exhibited significant activity against all tested bacteria and fungi. The highest inhibition zone $(1.35 \pm 0.04 \mathrm{~cm})$ was observed in acetone extract against $S$. typhimurium. While, petroleum ether extract of $S$. platensis was recorded the minimum activities of all tested antimicrobial and the lowest inhibition zone against Staphylococcus aureus $(0.52 \pm 0.01 \mathrm{~cm})$. The antioxidant potential of different solvent extracts clearly that acetone extract of $S$. platensis showed highest percentage of DPPH (2, 2 diphenyl-1picrylhydrazyl) scavenging activity $(75 \%)$ and highest values of phenolic contents $(0.562$ $\mathrm{mg} / \mathrm{g} \mathrm{DW})$. S. platensis displayed anticancer activity due to the productions of phycocyanin, allophycocyanin and other valuable products. Calf Serum was used to evaluate the potentiality of various $S$. platensis extracts to control the tumor effects in vitro. The cell proliferation assay showed that petroleum ether extract at a concentration of $125 \mu \mathrm{g} \mathrm{ml}^{-1}$ for $24 \mathrm{hrs}$, significantly inhibited the growth of the Fetal Calf tumor cells (13\% viability).
\end{abstract}

Keywords: Anticancer, Antimicrobial activity, Antioxidant, Cholesterol reduction, Spirulina platensis.

\section{Introduction}

Microorganisms have special properties and considered as a significant natural source of bioactive molecules, because they are capable of producing many bioactive compounds in culture medium, that are very difficult to be formed by chemical synthesis (Goud et al., 2007). Recently, there are remarkable trend in the industry of food for the development and production of functional products as a pharmaceuticals and nutraceuticals (Kasinathan et al., 2009). Microalgae are a large collection of photosynthetic microorganisms which can be isolated from different habitats, and also can be cultivated in commercial large-scale raceway ponds (Shao et al., 2019). Cyanobacteria or blue green algae are an ancient set of prokaryotic organisms which considered as a source for many secondary metabolites. Various strains of blue green algae can provide with many bioactive compounds that have various biological activities like antimicrobial agents, so it can be considered as good source for secondary metabolites, these secondary metabolites have a significant role in protections against many pathogens (Ghasemi et al., 2007). Spirulina, a filamentous cyanobacterium, is widely distributed in nature, due to the occurrence in different habitats, there are many biologists and pharmacists found that spirulina is an excellent source for many compounds. Previously, Spirulina was used as source of protein, some vitamins, specially

Corresponding author email: dr.soad_mohi@hotmail.com

Received 13/4/2019; Accepted 15/10/2019

DOI: 10.21608/ejbo.2019.11910.1306

Edited by: Prof. Dr. Wael S. El-Sayed, Faculty of Science, Ain Shams University, Cairo, Egypt.

(C)2020 National Information and Documentation Center (NIDOC) 
vitamin B12 and provitamin A and fatty acids like $\gamma$-linolenic acid.

Further interest has been given for studying the curative effects of spirulina, that have the ability to reduce cholesterol level and heavy metals nephrotoxicity, anticancer characteristics and immune system enhancement (Belay et al., 1994). Khan et al. (2005) reported that spirulina possess some another biological functions like antimicrobial and antiparasitic activities. Spirulina platensis have wide a broad of health benefits as the decrease of cholesterol level, protection against allergenic diseases, antimicrobial and anticancer activities (Konícková et al., 2014).

Chaitra et al. (2015) reported that in large-scale screening, more than 15,000 chemical compounds were isolated from micro algae that grow in marine environments such as steroids, polyphenolics, enzymes, polysaccharides, flavonoid, tannins, alkaloid compounds and many fatty acids, and newly investigations have shown the presence of many antioxidants.

At present, there are many health problems in the world, such as bacterial resistance to antibiotics. There are many efforts to obtain many biologically active compounds from natural sources all over the world, the marine microalgae and cyanobacteria are considered as the best among these natural resources because they can grow efficiently in large-scale raceway ponds or photobioreactors. In addition, the biological activity of algal extracts has been verified in medical fields as antimicrobial (Tuney et al., 2006).

There are many of researchers reported that Spirulina has become a medicinal food because it have good proteins, balanced fatty acids, vitamins, antioxidant compounds and many minerals, that make it able to participate in controlling many health problems like high cholesterol, as well as to decrease body weight in humans (Shao et al., 2019) and (Ramamoorthy \& Premakumari, 1996).

Cancer is one of the most serious diseases that causes harmful to human health in the world. Chemotherapy is still utilized as a standard treatment till now, most anti-cancer drugs used in chemotherapy are toxic to healthy normal cells and causes a lack of immunity, which affects not only the development of tumors but also it has a negative impact on the health of the patient. It has become necessary to find other new antitumor drugs that have limited side effects on the immune system and the general health of the patient (Shao et al., 2019).

The aim of the present study was to evaluate some biological activities of $S$. platensis extracts.

\section{$\underline{\text { Materials and Methods }}$}

Organism

The blue green microalga Spirulina platensis (Nordstedt) Geitler (Oscillatoiales) was obtained from the Culture Collection of the Algal laboratory, Faculty of Science, Alexandria University, Egypt. The powdered sample was stored in refrigerator for further use.

\section{Preparation of extracts}

Algal extracts were prepared according to the method of Kannan et al. (2013).

Extraction of the bioactive algal powder has been carried out by using four different organic solvents such as petroleum ether, chloroform, acetone and methanol as follows; ten grams of powdered sample were soaked in $50 \mathrm{ml}$ of mentioned above organic solvents. The samples were kept in the dark for $72 \mathrm{hrs}$ at room temperature (cold percolation) with intermittent shaking. After incubation, the solution was filtered through filter paper, and the filtrate was collected (crude extracts) and stored in the refrigerator until further use.

Evaluation of Antioxidant activity by DPPH free radicals scavenging assay

The algal extract was tested as antioxidant activity by 2, 2diphenyl-1 - picrylhydrazyl (DPPH) test according to the method of Yen \& Chen (1995). One $\mathrm{ml}$ of $0.003 \mathrm{~g}$ DPPH in $50 \mathrm{ml}$ methanol were mixed to $1.0 \mathrm{ml}$ algal extract and incubated for 30 minutes at room temperature, the absorbance was measured at $517 \mathrm{~nm}$ by Spectrophotometer Unico UV-2000 spectrophotometer. Gallic acid was used as positive control. The antioxidant capacity was calculated according to the following equation:

$$
\text { Scavenging activity } \%=(B-S / B) X 100
$$

where, (S) Absorbance of sample and (B) absorbance of blank. 


\section{Total phenolic content}

The algal extracts were examined of total phenolic content by Taga method (Taga et al., 1984). One ml of extract was mixed with $750 \mu 1$ Folin Ciocalteau's phenol diluted ten times and allowed to stand for $5 \mathrm{~min}$ then added $750 \mu \mathrm{l}$ of $6 \% \mathrm{Na}_{2} \mathrm{CO}_{3}$ and left in dark for $90 \mathrm{~min}$ at room temperature. Total phenolic contents were measured by spectrophotometer at $720 \mathrm{~nm}$. The standard curve was prepared using Tannic acid.

\section{Cholesterol binding assay}

Various concentrations $(200,400,600,800$ and $1000 \mu \mathrm{g} / \mathrm{ml}$ ) of cell lysates and intact cells for S. platensis were prepared from stock of $10 \mathrm{mg}$ of lyophilised cells per $\mathrm{ml}$ suspended in $1 \mathrm{ml}$ of

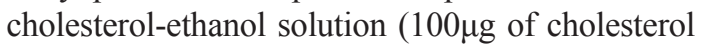
dissolved in one $\mathrm{ml}$ of ethanol $60 \%$ ), shaking well by vortex and incubated at $37^{\circ} \mathrm{C}$ for one hour in a shaking water bath. Then the mixtures were centrifuged at $1118 \mathrm{~g}$ for $10 \mathrm{~min}$ and unrestricted cholesterol in the supernatant was estimated by enzymatic analysis and the tests were repeated in triplicate. The kits of enzymatic colorimetric used for the estimation of cholesterol was obtained from Biodiagnostic Company Dokki, Giza, Egypt (Richmond, 1973). The absorbance of the sample and standard against blank was measured at $517 \mathrm{~nm}$. The percentage of cholesterol lowering effect was determined by this equation:

\section{Cholesterol reduction $(\%)=\mathrm{A} 517$ standard $-\mathrm{A} 517$ sample $\times$ 100/A517 standard.}

\section{Tested of bacteria and fungi}

The microorganisms used for the antimicrobial activity assay including two-gram positive bacteria (Staphylococcus aureus and Bacillus subtilis), two-gram negative bacteria (Escherichia coli and Salmonella typhimurium) and two fungi (Aspergillus flavus and Aspergillus niger). The microbial strains were provided from National Institute of Oceanography and Fisheries, Alexandria, Egypt. These strains were maintained on nutrient agar slant. The bacterial stock cultures were maintained on Mueller Hinton agar medium at $4^{\circ} \mathrm{C}$ and fungal cultures were maintained on Sabouraud Dextrose Agar (SDA) medium at $4^{\circ} \mathrm{C}$. A loop full of each of the microorganisms was suspended in about $10 \mathrm{ml}$ of saline in a Roux bottle. Each of these were streaked on to the suitable culture slants and incubated at $37^{\circ} \mathrm{C}$ for $24 \mathrm{hrs}$.

\section{Antibiotic susceptibility test}

The antimicrobial sensitivity of the bacterial and fungal strains was assessed by using the standard CLSI disk diffusion method due to the Clinical and Laboratory Standards Institute (CLSI, 2012). The antimicrobial agents from various classes of antibiotics with the following concentrations were checked: Ampicillin (AMP, $10 \mu \mathrm{g})$, Amoxicillin (AX, 15 $\mu \mathrm{g})$, Oxacillin (OX, $1 \mu \mathrm{g})$, Cefixime (CFM, 10 $\mu \mathrm{g})$, Ceftazidime (CZA, $30 \mu \mathrm{g})$, Ciprofloxacin (CIP, $5 \mu \mathrm{g}$ ), Imipenem (IPM, $10 \mu \mathrm{g})$, Chloramphenicol $(\mathrm{C}, 30 \mu \mathrm{g})$, Gentamicin

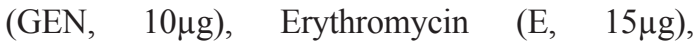

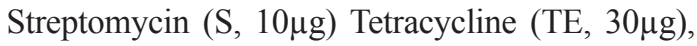
Nalidixic acid (NA, 30 $\mathrm{g}$ ), Ofloxacin ( OF, $5 \mu \mathrm{g}$ ), Vancomycin (VA, 30 $\mu \mathrm{g}$ ), Miconazole (MIC, $25 \mu \mathrm{g}$ ), Fluconazole (FLU, 25 $\mu \mathrm{g}$ ) and Itraconazole (ITR, $25 \mu \mathrm{g})$. Antibiotic discs were then used to the agar plates and incubated at $37^{\circ} \mathrm{C}$ for $24 \mathrm{hrs}$ then, the different growth inhibition zones of microbes were measured (mm). Calculate the multiple antibiotic resistances (MAR) to each microbe (total number of antibiotics which the microbe is resistant/ Total number of antibiotics checked) (Jayaraman et al., 2012).

\section{Antimicrobial assay}

The antimicrobial activity of different extracts of S. platensis was assessed by using disk diffusion method (Okigbo et al., 2005). Filter paper disks of $(5 \mathrm{~mm})$ in a diameter were prepared from Whatman filter paper. The antibacterial test using gram $+v e$ and gram -ve bacteria, were carried out using the agar plate method. The bacterial inoculum was grown in nutrient broth and a fixed volume $\left(1 \times 10^{6}\right)$ spores $/ \mathrm{ml}$ of different bacterium was prepared and $0.2 \mathrm{~mL}$ spore suspension was inoculated into $10 \mathrm{ml}$ aliquots nutrient agar, mixed and then poured over a nutrient agar base in sterile Petri dishes. After bacterial lawn was solidified, the paper disk of $5 \mathrm{~mm}$ was saturated with $5 \mu \mathrm{L}$ of each extract and placed in it. The plates were incubated at $30^{\circ} \mathrm{C}$ for $24 \mathrm{hrs}$ for bacterial strains. In another set of experiments for bioassay of fungal, sterile filter paper discs of $5 \mathrm{~mm}$ diameter were impregnated with $0.1 \mathrm{ml} / \mathrm{disc}$ of each extract and placed in duplicates onto SDA plates seeded with $0.1 \mathrm{ml}$ of fungal suspension. The plates were then incubated at $37^{\circ} \mathrm{C}$ for $25^{\circ} \mathrm{C}$ for 5 days (Saadabi et al., 2012). Standard antibiotic disk (Ampicillin and Miconazole) used as positive control and negative controls were prepared by using different solvents. Zones of inhibition were recorded as antimicrobial activity in $\mathrm{cm}$. All experiments were performed in triplicates. 


\section{Cytotoxicity assay}

Cell line and culture:

The cancer cell lines Supplied by VACSERA. (Holding Company for Vaccines and Sera). Cancer cells were seeded in flask with RPMI (Roswell Park Memorial Institute) media with $2-10 \%$ Fetal Calf Serum (FCS) and incubated at $37^{\circ} \mathrm{C}$ in a $5 \%$ $\mathrm{CO} 2$. After $24 \mathrm{hrs}$ incubation period the attached cells were trypsinizated. The cells were counted and distributed in 96 well ELISA plate. The plate was incubated $24 \mathrm{hrs}$ at $37^{\circ} \mathrm{C}$ in a $5 \% \mathrm{CO}_{2}$ atmosphere to allow the cells attach to the bottom of the well (AshaRani et al., 2009).

MTT Cytotoxicity assay

Evaluation of cell viability by the MTT [3-(4, 5-dimetheylthiazol-2)-2, 5 diphenyl tetrazolium bromide] colorimetric method with some modifications. Cells $\left(1 \times 10^{5} /\right.$ well $)$ were plated in one $\mathrm{ml}$ of medium/well in 24-well plates (Costar Corning, Rochester, NY). After incubation 48hrs the cell reaches the confluence. Then, cells were incubated in the presence of various concentrations of the samples in $0.1 \%$ DMSO (dimethyl sulfoxide) for $48 \mathrm{hrs}$ at $37^{\circ} \mathrm{C}$. After removal of the sample solution and washing with phosphate-buffered saline (pH 7.4), 200 $\mu \mathrm{l} / \mathrm{well}(5 \mathrm{mg} / \mathrm{ml})$ of $0.5 \% 3-(4$, 5-dimethyl-2-thiazolyl)-2, 5-diphenyl-tetrazolium bromide cells (MTT) solution was added. After $4 \mathrm{hrs}$ incubation, $0.04 \mathrm{M} \mathrm{HCl} /$ isopropanol were added. Viable cells were determined by the absorbance at $595 \mathrm{~nm}$. Measurements were performed and the concentration required for a $50 \%$ inhibition of viability (IC50) was determined graphically. The absorbance at $595 \mathrm{~nm}$ was measured with a UV- Spectrophotometer using wells without sample containing cells as blanks. Each experiment was done in triplicate. The relative cell viability (\%) related to control wells containing cell culture medium without sample as a vehicle was calculated (Mosmann, 1983):

$\%$ cell viability $=$ A595 of treated cells/ A595 of control cells X 100.

\section{Statistical analysis}

All experiments were carried out three times independently, and data were recorded as the means \pm standard deviation (SD) of the three replicates. Statistical analysis was performed using SPSS (Statistical Package for the Social Sciences) version 5. One-way ANOVA test was used to compare the differences between the mean value of each test. Significance of the obtained results was judged at the $5 \%$ level.

\section{Results}

Antioxidant activity assessed by the DPPH method

Figure 1 denoted that the DPPH radical scavenging activity of $S$. platensis in different solvent extracts with different concentrations. Various extracts of $S$. platensis possessed the ability to scavenge DPPH substantially in a concentration-dependent fashion and a type of solvent dependent used. S. platensis acetone extract had the most efficient free radical scavenging capacity, followed by methanol extract and chloroform. The lowest scavenging activity was recorded in petroleum ether extract. The increases in free radical scavenging activity were dependent on the concentration increased in all extracts. The results indicated that the radical scavenging ability of $S$. platensis acetone extract may result in significant antioxidant effects.

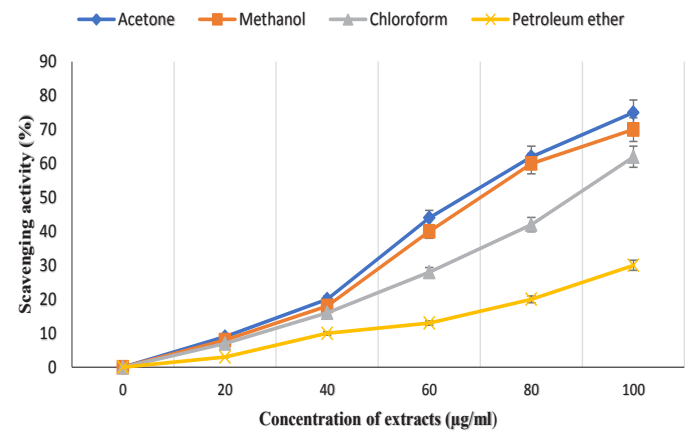

Fig. 1. DPPH radical scavenging of various extracts of spirulina platensis. The error bars indicate mean \pm SD $(n=3)$.

Phenolic contents

The results of phenolic contents are presented in Table 1 indicated that the acetone extract of $S$. platensis had more phenolic content, followed by methanol extract, chloroform and petroleum ether $(0.562,0.465,0.430$ and $0.050 \mathrm{mg} / \mathrm{g} \mathrm{DW})$ respectively, which are significantly different at $\mathrm{P}>0.05$

\section{Cholesterol reduction}

The percentage reduction of cholesterol by $S$. platensis was obtained in Table 1. Results indicate that different extracts of $S$. platensis have a high effect on the cholesterol reduction by using various solvents except petroleum ether which recorded a minute effect in the reduction of cholesterol 
under all treatments. Maximum percentages of cholesterol reduction were obtained by acetone followed by methanol, chloroform and petroleum ether under all treatments as the following 78.1, $73.0,65.2$ and $5.6 \%$, respectively, which are significantly different at $\mathrm{P}>0.05$.

Antibiotic resistant profiles (ARP) to the standard strains

The resistance of bacterial strains to various tested antibiotics was presented in Table 2. The standard strain of $S$. aureus was sensitive to (AX, CIP, IPM, C, GEN, S, NA and VA) and resistant to all antibiotic checked. The standard strain $B$. subtilis was sensitive to (C, CFM, GEN, S, TE and VA) and resistant to all antibiotic tested. The standard strain of $E$. coli was sensitive to (CIP, IPM, C, E, NA and OF) and resistant to (AMP, AX, OX, CFM, CZA, GEN, S, TE, VA, MIC, FLU and ITR). The standard strain of $S$. typhimurium was sensitive to (CZA, CIP, $\mathrm{C}, \mathrm{GEN}, \mathrm{S}, \mathrm{NA}$ and $\mathrm{OF}$ ) and resistant to all antibiotic tested. The standard strains of A. flavus and $A$. niger were resistant to all antibiotic tested except MIC, FLU and ITR. The data of multiple antibiotic resistances (MAR) indicated that all standard tested microbes have a high values of MAR.

TABLE 1. Phenol contents (mg/g DW) and Cholesterol reduction (\%) of Spirulina platensis extracted by using different solvents.

\begin{tabular}{llccc}
\hline Test & Methanol & Acetone & Chloroform & Petroleum ether \\
\hline Phenol contents & $0.465+0.22^{\mathrm{a}}$ & $0.562+0.3^{\mathrm{a}}$ & $0.430+0.1^{\mathrm{a}}$ & $0.050+0.23^{\mathrm{b}}$ \\
Cholesterol reduction & $73.0+0.1^{\mathrm{b}}$ & $78.1+0.2^{\mathrm{a}}$ & $65.2+0.3^{\mathrm{c}}$ & $5.6+0.3^{\mathrm{d}}$ \\
\hline
\end{tabular}

- Mean and standard deviation of three replicates are shown.

- Values in the same row with different superscripts letters are significantly different $(\mathrm{P}<0.05)$.

TABLE 2. Antibiotic resistant profiles (ARP) to the standard strains.

\begin{tabular}{lcccccc}
\hline Antimicrobial code & S. aureus & B. subtilis & E. coli & S. typhimurium & A. flavus & A. niger \\
\hline AMP & $\mathrm{R}$ & $\mathrm{R}$ & $\mathrm{R}$ & $\mathrm{R}$ & $\mathrm{R}$ & $\mathrm{R}$ \\
AX & $\mathrm{S}$ & $\mathrm{R}$ & $\mathrm{R}$ & $\mathrm{R}$ & $\mathrm{R}$ & $\mathrm{R}$ \\
OX & $\mathrm{R}$ & $\mathrm{R}$ & $\mathrm{R}$ & $\mathrm{R}$ & $\mathrm{R}$ & $\mathrm{R}$ \\
CFM & $\mathrm{R}$ & $\mathrm{S}$ & $\mathrm{R}$ & $\mathrm{R}$ & $\mathrm{R}$ & $\mathrm{R}$ \\
CZA & $\mathrm{R}$ & $\mathrm{R}$ & $\mathrm{R}$ & $\mathrm{S}$ & $\mathrm{R}$ & $\mathrm{R}$ \\
CIP & $\mathrm{S}$ & $\mathrm{R}$ & $\mathrm{S}$ & $\mathrm{S}$ & $\mathrm{R}$ & $\mathrm{R}$ \\
IPM & $\mathrm{S}$ & $\mathrm{R}$ & $\mathrm{S}$ & $\mathrm{R}$ & $\mathrm{R}$ & $\mathrm{R}$ \\
$\mathrm{C}$ & $\mathrm{S}$ & $\mathrm{S}$ & $\mathrm{S}$ & $\mathrm{S}$ & $\mathrm{R}$ & $\mathrm{R}$ \\
GEN & $\mathrm{S}$ & $\mathrm{S}$ & $\mathrm{R}$ & $\mathrm{S}$ & $\mathrm{R}$ & $\mathrm{R}$ \\
E & $\mathrm{R}$ & $\mathrm{R}$ & $\mathrm{S}$ & $\mathrm{R}$ & $\mathrm{R}$ & $\mathrm{R}$ \\
$\mathrm{S}$ & $\mathrm{S}$ & $\mathrm{S}$ & $\mathrm{R}$ & $\mathrm{S}$ & $\mathrm{R}$ & $\mathrm{R}$ \\
TE & $\mathrm{R}$ & $\mathrm{S}$ & $\mathrm{R}$ & $\mathrm{R}$ & $\mathrm{R}$ & $\mathrm{R}$ \\
NA & $\mathrm{S}$ & $\mathrm{R}$ & $\mathrm{S}$ & $\mathrm{S}$ & $\mathrm{R}$ & $\mathrm{R}$ \\
OF & $\mathrm{R}$ & $\mathrm{R}$ & $\mathrm{S}$ & $\mathrm{S}$ & $\mathrm{R}$ & $\mathrm{R}$ \\
VA & $\mathrm{S}$ & $\mathrm{S}$ & $\mathrm{R}$ & $\mathrm{R}$ & $\mathrm{R}$ & $\mathrm{R}$ \\
MIC & $\mathrm{R}$ & $\mathrm{R}$ & $\mathrm{R}$ & $\mathrm{R}$ & $\mathrm{S}$ & $\mathrm{S}$ \\
FLU & $\mathrm{R}$ & $\mathrm{R}$ & $\mathrm{R}$ & $\mathrm{R}$ & $\mathrm{S}$ & $\mathrm{S}$ \\
$\mathrm{ITR}$ & $\mathrm{R}$ & $\mathrm{R}$ & $\mathrm{R}$ & $\mathrm{R}$ & $\mathrm{S}$ & $\mathrm{S}$ \\
(MAR) & 0.56 & 0.67 & 0.67 & 0.61 & 0.83 & 0.83 \\
\hline
\end{tabular}

$\mathrm{R}=$ Resistant, $\mathrm{S}=$ Sensitive 


\section{Antimicrobial activity}

The antimicrobial activity of $S$. platensis extracts of different solvents (Methanol, Acetone, Chloroform and Petroleum ether) were studied against $S$. aureus, B. subtilus, E. coli and $S$. typhimurium, A. flavus and A. niger are presented in Table 3. The method was used to evaluate the antimicrobial activity by disc diffusion, where the inhibition zone against fungi and bacteria were measured in $(\mathrm{cm})$. Acetone extract of S. platensis has exhibited the prominent antimicrobial activity of all the antimicrobial under all treatments but was more susceptible against $S$. typhimurium which recorded the maximum inhibition zone $1.35 \pm 0.1 \mathrm{~cm}$. While, petroleum ether extract of $S$. platensis was recorded the minimum activities of all tested antimicrobial but was less susceptible against $S$. aureus $0.52 \pm 0.04 \mathrm{~cm}$. The chloroform extract of $S$. platensis also resembles nearly the same activities as acetone extract. Acetone extract was the most potent antimicrobial fractions and also significantly inhibited the growth of microbes used.

Anticancer activity of Spirulina platensis extracts

Anticancer activities were evaluated in order to elucidate the effect of different extracts is directly correlated to the induction of cell death or the suppression of cell proliferation. The results of anticancer activity of different extracts of $S$. platensis are summarized in Table 4.

In this investigation, the MTT assay was evaluated to study anticancer activity of $S$. platensis with various concentrations in between 7.8 to $1000 \mu \mathrm{g} / \mathrm{ml}$ of different extracts of $S$. platensis. Anticancer effect of different extracts of $S$. platensis was observed in Fetal Calf Serum Cell Line. At low concentration of the different extracts $(7.8 \mu \mathrm{g} /$ $\mathrm{ml})$, the viability of the cells was found to be increased, while at a high extract concentrations of $S$. platensis, it was accompanied by decreasing the cell viability. Acetone extract of S. platensis exhibited the prominent anticancer activity for all solvents used. The maximum anticancer activities of different extracts were recorded as the following: acetone $>$ Petroleum ether $>$ Chloroform $>$ methanol where the $\mathrm{LC}_{50}$ (Lethal concentration) of various extracts were observed at 31, 38, 96 and $98 \mu \mathrm{g} / \mathrm{ml}$, respectively.

TABLE 3. Antimicrobial activity of Spirulina platensis against multidrug resistant standard microbial strains.

\begin{tabular}{lccc}
\hline Pathogenic & Solvent & Mean of inhibition zone (cm) & Antibiotic disc (cm) \\
\hline \multirow{3}{*}{ S. aureus } & Methanol & $0.78 \pm 0.01$ & $0.75 \pm 0.02$ \\
& Acetone & $0.92 \pm 0.01$ & $1.06 \pm 0.3$ \\
& Chloroform & $0.89 \pm 0.01$ & $1.10 \pm 0.2$ \\
Petroleum ether & $0.52 \pm 0.04$ & $1.08 \pm 0.1$ \\
\hline B. subtilis & Methanol & $0.81 \pm 0.01$ & $0.92 \pm 0.5$ \\
& Acetone & $0.92 \pm 0.01$ & $1.02 \pm 0.2$ \\
& Chloroform & $0.85 \pm 0.02$ & $1.04 \pm 0.05$ \\
E. coli & Petroleum ether & $0.55 \pm 0.01$ & $0.72 \pm 0.2$ \\
\hline Methanol & $0.69 \pm 0.01$ & $0.92 \pm 0.5$ \\
S. typhimurium & Acetone & $0.91 \pm 0.01$ & $0.74 \pm 0.2$ \\
& Chloroform & $0.88 \pm 0.02$ & $1.05 \pm 0.2$ \\
& Petroleum ether & $0.65 \pm 0.01$ & $0.65 \pm 0.1$ \\
\hline Methanol & $0.85 \pm 0.02$ & $0.83 \pm 0.3$ \\
A. flavus & Acetone & $1.35 \pm 0.1 * *$ & $0.78 \pm 0.2$ \\
& Chloroform & $1.04 \pm 0.01 *$ & $0.93 \pm 0.1$ \\
& Petroleum ether & $0.86 \pm 0.03$ & $0.72 \pm 0.1$ \\
\hline & Methanol & $0.56 \pm 0.2$ & $1.06 \pm 0.22$ \\
& Acetone & $0.89 \pm 0.04$ & $0.73 \pm 0.2$ \\
& Chloroform & $0.68 \pm 0.05$ & $1.02 \pm 0.5$ \\
& Petroleum ether & $0.54 \pm 0.01$ & $1.05 \pm 0.3$ \\
\hline & Methanol & $0.84 \pm 0.01$ & $0.94 \pm 0.1$ \\
& Acetone & $0.89 \pm 0.02$ & $0.72 \pm 0.2$ \\
& Chloroform & $0.65 \pm 0.04$ & $0.96 \pm 0.2$ \\
& $0.54 \pm 0.5$ & $1.05 \pm 0.1$ \\
\hline
\end{tabular}

*Significant at $\mathrm{P}<0.05$. 


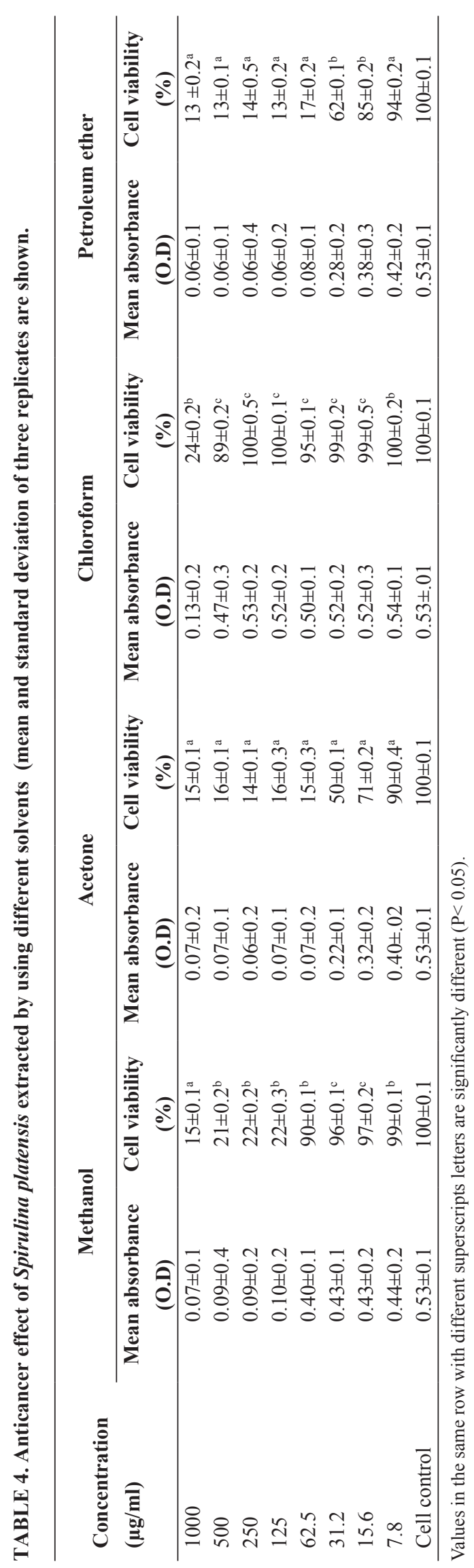

\section{Discussion}

Spirulina platensis can be considered as wealthy source of many novel bioactive compounds which have various application in pharmaceutical industries. Bleakley \& Hayes (2017) reported that Spirulina is the greatest microalgal consumed, which utilized as a source of healthy human food for many centuries, besides it has highly nutritional values, which have many biological activities such as antioxidant, antimicrobial and anticancer. S.platensis biomass had high antioxidant activity supporting its use as nutritional supplement (Taga et al., 1984). S. platensis biomass contains phycobiliproteins, phycocyanin and alophycocyanin, which have antioxidant properties (Estrada et al., 2001). Baicus \& Baicus (2007) reported the antioxidant activity was attributed due to the presence of phenolic compounds in the methanol algal extract include of salicylic acid, chlorogenic, transcinnamic, caffeic acids, quimic and synaptic; individually or in a synergistic action. Abomohra et al (2016) reported that gama radiation induce to the (ROS) cellular reactive oxygen species through the signaling purinergic which stimulate the Arthrospira platensis cells to increase the production of antioxidants under the oxidative stress. Viswanathan et al. (2014) was recorded there are many literature reports indicated that the manifestation of total antioxidant capacity of sample is based on single electron transfer (SET) and hydrogen atom transfer (HAT) mechanisms. My results clarified that Spirulina platensis acetone extract had the most efficient scavenging capacity, thus can conclude that the efficacies of antioxidants are often associated with their ability to scavenge stable free radicals. Therefore, the DPPH radical scavenging activity of acetone extract of $S$. platensis demonstrated its oxygen radical absorbance capacity and indicated its potent antioxidant nature.

The results indicated that there is basically a positive relationship between antioxidant activity and total phenolic contents. In particular, the highest total phenolic contents of S. platensis acetone extract were related to its highest antiradical-antioxidant capacity. El Salhin et al. (2016) concluded that phenolic compounds have antioxidant characteristics and relevant biological properties. Phenolic compounds such as tannic, rutin and gallic acid gave high antioxidant capacity. Halimoon \& Ali (2010) reported that 
S. platensis contained significant amounts of phenolics compounds. Phenolic compounds found in algae have various health-promoting functions in humans (Islam et al., 2003).

Kamal et al. (2015) studied the treatment with intact cells or cell lysates of Lactobacillus and Spirulina to stimulate lowering effect of hypercholesteremia. Prakash \& Kumari (2011) were utilized Papaya pulp and Spirulina for preparation of low- fat and high-protein frozen yogurt. My results indicated that S. platensis extracts have the potentiality to reduce the level of cholesterol and maximum percentage reduction of cholesterol was obtained by acetone extract followed by methanol extract.

There are many researches have been reported as antimicrobial agents from microalgae, among this Spirulina, which can be considered as a rich source of natural antimicrobial agents. Kokou et al. (2012) reported that Spirulina have been inhibited growth of six strains of Vibrio, so that it can be considered as good antibacterial agents. Also, Özdemir et al. (2004) studied the effect of various extracts of $S$. platensis against bacteria and they were reported that methanol extract is the best for inhibit the growth of bacterial fraction. The present result was in agreement with those obtained by Santoyo et al. (2006) studied the effect of S. platensis extracts of ethanol, hexane and petroleum ether as antimicrobial activity against $E$. coli, S. aureus, A. niger and Candida albicans. Furthermore, the purified c-phycocyanin pigment of $S$. platensis was inhibited the growth of many strains of bacteria as $S$. aureus, E. coli, Klebsiella pneumonia and Pseudomonas aeruginosa (Sarada et al., 2011; Mohamed \& Saber, 2019). The results in Table 3 indicated that the acetone extract of $S$. platensis was the best solvent for inhibition the growth of A. flavus, A. niger., S. aureus, B. subtilus, E. coli and $S$. typhimurium, where the mean of inhibition zone of acetone extract $(0.912 \mathrm{~cm})$, followed by chloroform extract $(0.729 \mathrm{~cm})$, methanol extract $(0.683 \mathrm{~cm})$ and petroleum ether $(0.548 \mathrm{~cm})$.

There are strong evidences that, Spirulina have also with antitumor and anticancer functions. Many investigations were confirming that the potentiality of Spirulina extracts for the anticancer activities, either sole or in incorporation with other compounds. Schwartz \& Shklar (1987) used 20 animals to study the effect of
Spirulina extracts on the induced squamous cell carcinoma of hamster buccal pouches and the data were shown that phycotene of spirulina causes the regression about $30 \%$ of the total tumor of the treated animals, whilst $\beta$-carotene and canthaxanthin were controlled to the regression of tumor about $20 \%$ and $15 \%$ of treated animals, respectively. Schwartz et al. (1988) studied how Spirulina-Dunaliella extracts prevent oral cancer and they concluded that the extract of spirulina enhances and stimulates the immune responses that destroys small foci of developing malignant cells without any side effect to the normal cells. Liu et al. (2000) studied the inhibitory effects of c-phycocyanin from $S$. platensis on the growth of human leukemia $\mathrm{K}_{562}$ cells, the study concluded that about $50 \%$ of the leukemia cells were controlled after 12 days of treatment use Spirulina phycocyanin. Moreover, Subhashini et al. (2004) found that about $49 \%$ of the $\mathrm{K}_{562}$ cell proliferation was inhibited by using with $50 \mu \mathrm{M}$ of purified phycocyanin from $S$. platensis through 48hrs. Choi et al. (2013) studied the effect of Spirulina maxima grown in deep marine water, which stimulate the immune activity and they are concluded that the higher effective stress of $\mathrm{Bc}_{12}$ gene in $\mathrm{A}_{549}$ cells causes the human cancer inhibition in different cells. Kawanishi et al. (2013) reported the complicated polysaccharide obtained from Spirulina have the ability to inhibit the growth of glioma cell through lowering regulation angiogenesis by the regulation of production of interleukin-17. All these pervious findings supported our results for anticancer effect of S. platensis extracts in Fetal Calf Serum Cell Line. At low concentration of $S$. platensis extracts $(7.8 \mu \mathrm{g} / \mathrm{ml})$, the cell viability was found to be increased, whilst at a high concentration of extracts, it was accompanied by decreased of the cell viability. Acetone extract of $S$. platensis has exhibited the prominent anticancer activity of all solvent used.

\section{Conclusion}

There are many scientific reports indicating the possibility of using $S$. platensis in the treatment of many diseases due to the possible synergetic effect of many phytochemicals in the cell. From this study, it can be concluded that S. platensis have antimicrobial efficiency, antioxidant capacity, anticancer efficiency and its cholesterol-lowering effects depending on type of solvent used for algal extraction. Acetone was the most effective 
solvent for extraction of bioactive compounds from S. platensis. So, S. platensis can serves as very important potential source of many bioactive products with commercial impact. Further study should be done for isolation and purifying the effective compounds, which will demonstrate their utility in the pharmaceuticals and biological industries.

Acknowledgments: My sincere gratitude to Dr. Nadia Noaman, Professor of phycology at Faculty of Science in Alexandria University for providing the nonliving Spirulina platensis.

The Conflict of Interest Statement: The authors declare that they have no conflict of interest.

The article is original, has not been formally published in any other peer-reviewed journal, is not under consideration by any other journal and does not infringe any existing copyright or any other third-party rights.

\section{References}

AshaRani, P.V., Low Kah Mun, G., Hande, M.P., Valiyaveettil, S. (2009) Cytotoxicity and genotoxicity of silver nanoparticles in human cells. ACS Nano. 3, 279-290.

Abomohra, A., El-Shouny, W., Sharaf, M., AboEleneen, M. (2016) Effect of gamma radiation on growth and metabolic activities of Arthrospira platensis. Braz. Arch. Biol. Technol. 59, e16150476.

Baicus, C., Baicus, A. (2007) Spirulina did not ameliorate idiopathic chronic fatigue in four N-of1 randomized controlled trials. Phytother. Res. 21, $570-573$.

Belay, A., Ota, Y., Miyakawa, K., Shimamatsu, H. (1994) Production of high quality Spirulina at Earthrise Farms. In: "Algal Biotechnology in the Asia-Pacific Region", Phang et al. (Eds.), pp. 92102. University of Malaya.

Bleakley, S., Hayes, M. (2017) Algal proteins: Extraction, application, and challenges concerning production. Foods, 6, 33.

Chaitra, Kapfo, W., Chauhan, J.B. (2015) Phytochemical screening and estimation of value added compounds from Nostoc linckia. Sch.Acad. J. Biosci. 3, 762-765.
Choi, W.Y., Kang, D.H., Lee, H.Y. (2013) Enhancement of immune activation activities of Spirulina maxima grown in deep sea water. Int. J. Mol. Sci. 14, 12205 12221.

CLSI (2012) Performance standards for antimicrobial disk susceptibility tests; approved standard, $11^{\text {th }} \mathrm{ed}$. CLSI document M02-A11, Vol. 32(1). Clinical and Laboratory Standards Institute, Wayne, PA.

El Salhin, H., Abobaker, Hanan M., Hasan, H.M., Jabraiel, A., Dayek, E. (2016) Antioxidant capacity and Total phenolic compounds of some algae species(Anabaena and Spirulina platensis). Scholars Academic Journal of Biosciences (SAJB), 4(10A), 782-786.

Estrada, J., Bescós, P., Villar Del Fresno, A. (2001) Antioxidant activity of different fractions of Spirulina platensis protean extract. J. IlFarmaco, 56, 497-500.

Ghasemi, Y., Moradian, A., Mohagheghzadeh, A., Shokravi, S., Morowvat, M.H. (2007) Antifungal and antibacterial activity of the microalgae collected from paddy fields of Iran: characterization of antimicrobial activity of Chroococcus disperses. J. Biol. Sci. 7, 904-910.

Goud, M.L, Seshika, AD., Charya, M.A.S. (2007) Antibacterial activity and biomolecular composition of certain freshwater micro-algae from river Godavari (India). Sci. World J. 2, 19-23.

Halimoon, N., Ali, R. (2010) Evaluation of antioxidative activity of phenolics in methanolic extracts of blue green algae. J. CATRINA, 5(1), 9-13.

Islam, M.S., Yoshimoto, Y., Yamakawa, O. (2003) Distribution and physiological functions of caffeoylquinic acid derivatives in leaves of sweet potato genotypes. J. Food Sci. 68, 111-6.

Jayaraman, S., Manoharan, M., Ilanchezian, S., Sekher, R., Sathyamurthy, S. (2012) Plasmid analysis and prevalence of multidrug resistant $S$. aureus reservoirs in Chennai city, India. Asian J. Pharmacol. Life Sci. 10, 117-125.

Kamal, S., Hamouda, R.A., Mahrous, H., Salem, M.L., Hamza, H.A., Abd Elhafez, E. (2015) In vitro treatment with intact cells or cell lysates of Lactobacillus and Spirulina induced lowering effects on induced hypercholesteremia. Inter. J. 
Pharma. 11, 638-643.

Kannan, R.R.R., Arumugam, R., Ramya, D., Manivannan, K., Anantharaman, P. (2013) Green synthesis of silver nanoparticles using marine macroalga Chaetomorpha linum. Appl. Nanosci. 3, 229-233.

Kasinathan, T., Duraipandiyan, V., Perumal, P., Igracimuthu, S. (2009) Antimicrobial activity of Trichodesmium erythraeum (microalgae) from south east coast of Tamil Nadu, India. Inter. J. Integr. Biol. 5, 167-170.

Kawanishi, Y., Tominaga, A., Okuyama, H., Fukuoka, S., Taguchi, T., Kusumoto, Y., Yawata, T., Fujimoto, Y., Ono, S., Shimizu, K. (2013) Regulatory effects of Spirulina complex polysaccharides on growth of murine RSV-M glioma cells through Toll-like receptor-4. Microbiology and Immunology, 57(1), 63-73.

Khan, M., Ather, A., Thompson, K., Gambari, R. (2005) Extracts and molecules from medicinal plants against herpes simplex viruses. Antiviral Res. 67, 107-119.

Konícková, R., Va nková, K., Vaníková, J., VA־nová, K., Muchová, L., Subhanová, I., Zadinová, M., Zelenka, J., Dvo rák, A., Kolár, M., Strnad, H., Rimpelova, S., Ruml, T., Wong, J.R., Vitek, L. (2014) Anti-cancer effects of blue-green alga Spirulina platensis, a natural source of bilirubinlike tetrapyrrolic compounds. J. Ann. Hepatol. 13, 273-283.

Kokou, F., Makridis, P., Kentouri, M., Divanach, P. (2012) Anti-bacterial activity in microalgae cultures. Aquacult. Res. 43, 1520-1527.

Liu, Y., Xu, L., Cheng, N., Lin, L., Zhang, C. (2000) Inhibitory effect of phycocyanin from Spirulina platensis on the growth of human leukemia K562 cells. J. Appl. Phycol. 12, 125-130.

Mohamed, S.S., Saber, A.A. (2019) Antifungal potential of the bioactive constituents in extracts of the mostly untapped brown seaweed Hormophysa cuneiformis from the Egyptian coastal waters. Egypt. J. Bot. 59(3), 695-708.

Mosmann, T. (1983) Rapid colorimetric assay for cellular growth and survival application to proliferation and cyto-toxicity assays. J. Immunol
Methods. 65(1-2), 55-63.

Okigbo, R.N., Mbajiuka, C.S., Njoku, C.O. (2005) Antimicrobial potentials of (UDA) Myopias aesthetical and Acetum gratissimum L. on some pathogens of man. Int. J. Mole. Med. Adv. Sci. 1, 392-397.

Özdemir, G., Karabay, N.U., Dalay, M.C., Pazarbasi, B. (2004) Antibacterial activity of volatile component and various extracts of Spirulina platensis. Phytother. Res. 18, 754-757.

Prakash, D.R., Kumari, P. (2011) Preparation of low- fat and high-protein frozen yogurt enriched with papaya pulp and Spirulina. Trends Biosci. 4, 182-184.

Ramamoorthy, A., Premakumari, S. (1996) Effect of supplementation of Spirulina on hyper cholesterolemic patients. J Food Sci Technol. 33, 124-128.

Richmond, W. (1973) Preparation and properties of a cholesterol oxidase from Nocardia sp. and its application to the enzymatic assay of total cholesterol in serum. Clin. Chem. 19, 1350-1356.

Saadabi, A.M.A., Ali, N.M., Mohammed, H.I., Alsafi, F.N., Mustafa, H.B. (2012) An in vitro antimicrobial activity of Calotropis procera (Ait). R. Br. extracts on certain groups of pathogenic microorganisms. Research Journal of Medical Sciences, 6(1), 13-17.

Santoyo, S., Herrero, S., Señorans, M., Cifuentes, F., Ibáñez, A., Lauva, J. (2006) Functional characterization of pressurized liquid extracts of Spirulina platensis. Eur. Food Res. Technol. 224, 75-81.

Sarada, D.L., Kumar, C.S., Rengasamy, R. (2011) Purified C-phycocyanin from Spirulina platensis (Nordstedt) Geitler: A novel and potent agent against drug resistant bacteria. World J. Microb. Biot. 27, 779-783.

Schwartz, J., Shklar, G. (1987) Regression of experimental hamster cancer by beta carotene and algae extracts. J. Oral. Maxillofacial Surg. 45, 510515.

Schwartz, J., Shklar, G., Reid, S., Trickler, D. (1988) Prevention of experimental oral cancer by extracts of Spirulina- Dunaliella algae. Nutrition Cancer, 11, 127-134. 
Shao, W., Ebaida, R., El-Sheekh, M., Abomohra, A., Eladel, H. (2019) Pharmaceutical applications and consequent environmental impacts of Spirulina (Arthrospira): An overview. Grasasy Aceites, 70(1), 1-12.

Subhashini, J., Mahipal, S.K., Reddy, M.C., Reddy, M.M., Rachamallu, A., Reddanna, P. (2004) Molecular mechanisms in C-Phycocyanin induced apoptosis in human chronic myeloid leukemia cell line- $\mathrm{K}_{562}$. Biochem. Pharmacol. 68, 453-462.

Taga, M., Miller, E., Pratt, D. (1984) Chia Seeds as a source of natural lipid antioxidants. J.Am. Oil Chem. Soc. 61, 928-931.
Tuney, I., Cadirci, B.H., Unal, D., Sukatar, A. (2006) Antimicrobial activities of the extracts of marine algae from the coast of Urla (Izmir, Turkey). Turk. J. Biol. 30, 171-175.

Viswanathan, S., Ebciba, C., Santhiya, R., Nallamuthu, S. (2014) Phytochemical screening and in vitro antibacterial, antioxidant and anticancer activity of Amphiro Fragilissima. Int. J. Innov. Res.Sci.: Eng. Technol. 3(5), 12933-12948.

Yen, G.H., Chen, H.Y. (1995) Antioxidant activity various tea extract in relation to their antimutagenicity. J. Agri. Food Chem. 43, 27-32.

\title{
تقييم الأنشطة البيولوجية المختلفة لمستخلصات سبيرولينا البلاتينية \\ سعاد محمد محمود محيي الاين \\ قسم النبات و الميكروبيولوجي ـ ملية العلوم - جامعة الإسكندريةـ الإسكندريةـ مصر.
}

\begin{abstract}
ان الأسبيروليناو احدة من الطحالب الخضر اء المزرقة وتعتبر مصدر جيد للأصباغ وخاصة الفيكوسيانين ج حيث

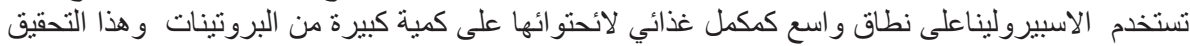

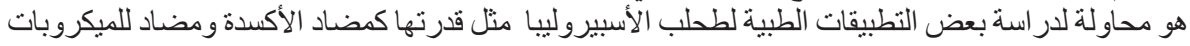

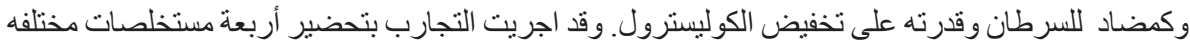

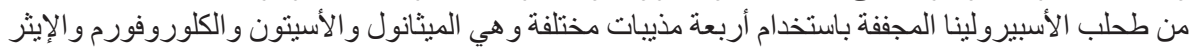

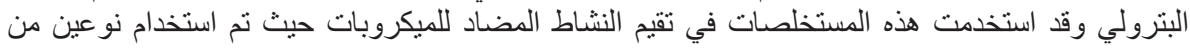
الفطريات وهما Aspergillus flavus and A. niger

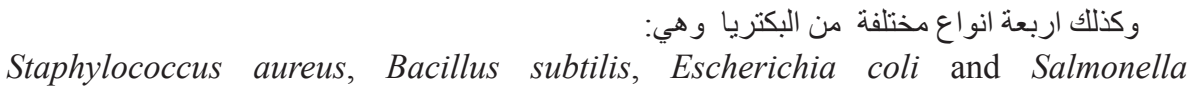
.typhimurium

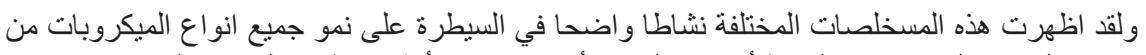

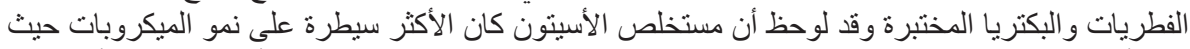

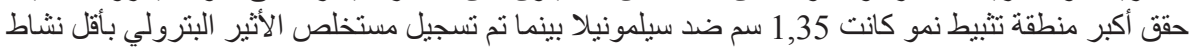

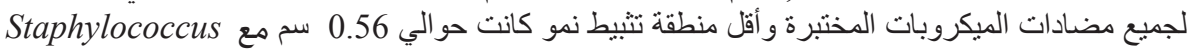
.aureus

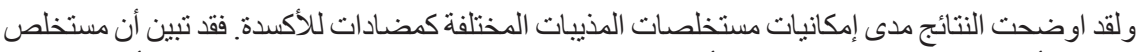

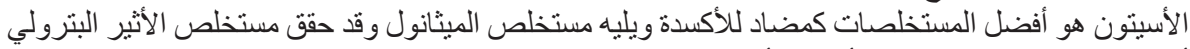

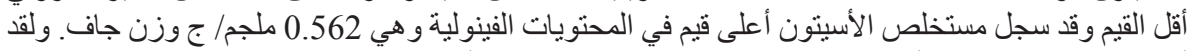

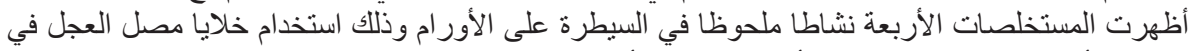

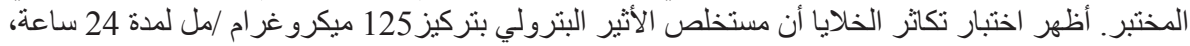

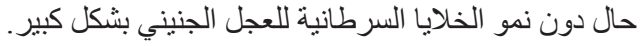

